Київська Академія 16 (2019): 205-211.

http://ka.ukma.edu.ua

Володимир Маслійчук

\title{
Fedyukin, Igor. The Enterprisers. The Politics of Schools in Early Modern Russia (Oxford: Oxford Univercity Press, 2019), 318 p.
}

Питання нової світської освіти пов'язане з державною політикою. На сучасному рівні одним із головних завдань вивчення доби Просвітництва $€$ висвітлення впливу меритократичних переконань на політику, що, своєю чергою, насуває питання про те, як гідних і талановитих вихідців із найрізноманітніших суспільних верств допускали до управління державою та які способи для цього вважали за доречні. Один із таких шляхів видається очевидним - завдяки освіті.

Ігор Федюкін $є$ досить помітним дослідником історії освіти, аналітиком освітніх проблем у низці видань 2010-2011 pp., а також одним із реформаторів і борців з плагіатом та речником реформування російської науки у 2012-2013 рр. (заступник міністра освіти та науки РФ, прихильник покарань за плагіат шляхом відкликання наукових ступенів та закриття вчених рад). Він отримав докторське звання в університеті Північної Кароліни (Чапелл-Гілл, США) 2009 р., нині працює у науково-дослідному університеті Вища школа економіки (Москва, РФ), де очолює Центр історії Росії нового часу Школи історичної науки. Історія освіти часів формування імперіїце багаторічне зацікавлення Ігоря Федюкіна.

У рецензованій праці історик досліджує основні освітні проекти та їхню реалізацію в Російській імперії першої половини XVIII ст., залишаючи для подальших студій університетські «змагання» та реформи пізнішого часу, зокрема просвітницький абсолютизм Катерини II, і не надаючи уваги Російській імператорській Академії наук та гімназії при ній (як і діяльності Григорія Теплова, Михайла 
Ломоносова та Кирила Розумовського). Але навіть таке «обмеження» ставить книжку Ігоря Федюкіна на чільне місце серед досліджень з історії освіти в Російській імперії.

Книжка складається із «засновків» (acknowledgments), вступу, шести розділів, висновків, приміток-посилань, списку літератури та покажчика. Назви розділів досить «художні», їх вочевидь розраховано на західного читача.

Вступ до книжки починається із розповіді про страту Сильвестра Медведєва, чільної постаті московського шкільництва та друкарства, за підтримку стрілецького бунту 11 лютого 1691 p. Утім, Медведєв цікавить автора передусім як основний редактор «Привиллегии на Академию» 1681 р., що заклала початок московському шкільництву. Власне звідси було започатковано низку освітніх проектів зі жвавими дискусіями, зокрема й зіткнення Медведєва з братами Ліхудами, засновниками Слов'яно-греко-латинської академії у Москві. Саме «Привиллегия» стала основою для створення нових шкіл та підставою для їхнього подальшого функціонування, а страта Медведєва символізувала великі зміни у світській владі. Мова про посідання престолу Петром I, тяжіння до реформування війська, зміни у фіскальній системі, великі інженерні побудови та загалом початок великих проектів і великих секуляризаційних новацій у політиці й освіті. Ужита автором дефініція «антрепенери» (The Enterprisers) (проектувальники, «прожектеры» - за висловом автора $^{1}$ ) найкраще позначає процеси в тогочасній освітній сфері, де задум відрізнявся від його реалізації і де індивідуальна, приватна ініціатива часто ставала визначальною для освітніх проектів.

У першому розділі книжки «Монахи, наставники і місіонери» шкільництво пізньої Московської держави розглядається як пов'язане із схоластичними впливами, особливо сусіднього православ'я «малоросів» та греків. Сам Петро I замолоду та під час подорожей Європою відвідував різноманітні навчальні заклади, серед іншого і єзуїтського типу, а утвердження «малоросійської партії» біля церковного керівництва імперією після смерті патріарха Адріана увінчалося привілеєм 12 вересня 1701 р. на підтвердження прав

${ }^{1}$ Игорь Федюкин, ““Прожектеры” как административные предприниматели: становление раннемодерных государственных институтов и индивидуальная инициатива,» в «Регулярная академия учреждена будет»: Образовательные проекты в России в первой половине XVIII века (Москва: Новое издательство, 2015), 3-13. 
і назви Києво-Могилянської академії. Однак, поруч із цим, було впроваджено й інакші заходи, як-от: висилка молоді для навчання морської справи за кордон 1697 р. та прийняття пропозицій щодо започаткування навчальних закладів. Перед нами істотні полілоги: нові католицькі та протестантські новації, впроваджувані у церковне життя через поступки «грецької партії» українським православним діячам Стефану Яворському, згодом Теофану Прокоповичу (с. 49), а також поява протестанських лютеранських місіонерів і лікарів (Германа Франке та пастора Ернста Глюка з проектом великої школи у Москві), що суттєво впливали на політичні рішення царя. Наслідком таких впливів став «Духовний регламент» (1721р.), особливо його пункти про освіту та опіку синодальної церкви над освітою.

Книжці Ігоря Федюкіна притаманне тяжіння до військової, солдатської школи - основного типу світської освіти, мабуть, аж до училищної реформи 80-х - 90-х pp. XVIII ст. Отож наступні розділи праці присвячуються власне цьому новому типові шкільництва, починаючи від Навігаційної школи за участи шотландця Генрі Фарварсона та її подальшої трансформації у Морську академію. Чергові розділи «Навігаційна школа та дільці (profit-maker)», «Морська академія та “самозванець барон без жодного диплому”» $\mathrm{i}$ «Морська академія та велика регуляція Петра Першого» передусім стосуються саме цих навчальних закладів. Чимало місця відведено директорові «школи навігаційних та математичних наук» Олексію Курбатову як автору сміливих пропозицій щодо змін в імперії та основному фундаторові Навігаційної школиㄴ․ За визначенням автора, погляди та пропозиції Курбатов являли собою «заскладне поєднання», де було мало безпосередньо «західного»; хоч і відзначено латинські контакти Курбатова (с. 67), однак відчувалися меркантилістичні спостереження і раціональні пропозиції-утім,

\footnotetext{
${ }^{2}$ Висловимо гадку про «українське» походження цього реформатора чи, принаймні, пов'язаність 3 «київською освітою» за багатьма опосередкованими ознаками, як-от: «елементи української графіки почерку» (Д. Серов, Администрация Петра Первого (Москва: ОГИ, 2007), 175; можливо, його міг навчити «малоросійський» священик у Москві); був «маршалком» при «домі» Бориса Шереметьєва, тривалий час білгородського воєводи, очільника слобідських полків; підтримував Теофана Прокоповича у справі скасування патріаршого престолу (Н. П. Павлов Сильванский, Проекты реборм в записках современников Петра Великого: Опьт изучения русских проектов и неизданнье их тексты (Санкт-Петербург: Тип. В. Киршбаума, 1897), 56-58, 63); контактував із гетьманом Іваном Мазепою (там само, 60).
} 
із помітним тяжінням до місцевих практик і православної риторики. Автор інтерпретує це як перехідну фазу від церковного до світського навчання, що виразно проявила себе на Заході у трансформації єзуїтських та протестантських навчальних закладів. 3 огляду на те, що Навігаційна школа знаходилася далеко від моря (в Сухарєвій вежі у Москві), на його думку, варто говорити радше про загальне, а не спеціальне навчання - як перший крок до створення професійного офіцерського складу регулярної армії.

Значною новацією стало перетворення Навігаційної школи (з переведенням іï учнів) в Морську академію 1715 р., цей розділ праці насичено інформаціями про барона Йозефа Сент Ілера, першого керівника цього закладу. Діяльність Сент Ілера та морські проблеми Британії, Франції, Іспанії (імперії Габсбургів) доти мало висвітлювалися у російській історіографії, тож тут натрапляємо на чимало авторських відкриттів щодо втягнення задуму морської школи в ширший контекст міжнародних проектів. Поза тим, барон Сент Ілер запровадив обов'язкове володіння іноземними мовами для навчання і французький мілітарний статут Людовика XIV у практику освітніх закладів. Початки «Морської академії» дійсно видаються значним трансфером нових ідей на російський грунт, однак чи не більшу роль у цьому зіграв Андрєй Матвєєв (це визнає і Ігор Федюкін) - перший директор Морської академії, що впродовж 1699-1715 рр. перебував при західних дворах, серед іншого й при дворі Людовика XIV. Проект барона Сент Ілера реалізовано не було, однак він ліг в основу регламентації навчання за «Морским уставом» 1720 р.: йому присвячено четвертий розділ книжки. Нові зміни пов'язувалися з тодішнім керівником Академії Григорієм Скорняковим-Писарєвим (особою, як і Курбатов, непевного соціального походження). Автор простежує подальшу долю «морського корпусу», визнаючи за Морською академію першість у регуляризації навчального процесу, дисциплінуванні учнів та появі світської освіти.

Окремий, п’ятий розділ Ігор Федюкін присвячує початкам Сухопутного Шляхетного (кадетського) корпусу та «німцям», позаяк більшість і вихованців, і вихователів корпусу спершу складали німецькомовні прибалтійські дворяни. Головним його «проектувальником» був Буркгард Крістоф Мініх, чия діяльність тісно пов'язувалася з домінуванням «німецької партії» на дворі Анни Іоанівни. Плани цього генерала виходили далеко за освітню сферу: йшлося 
i про перебудову столиці, і про прокладання Ладозького каналу, і про реформування управління імперією (зокрема в Сибіру). Утім, дані проекти залежали від політичної волі керівництва, а Сухопутний корпус являв собою лише частину великих мрій щодо політичних та економічних змін, урегулювання правління та перетворень у військовій сфері. Автор наводить чимало паралелей появи військових спеціалізованих навчальних закладів, зокрема у Франції 1751 р.

Останній розділ книжки під назвою «Франти, фаворити та інші реформатори» присвячено передусім Петру Шувалову, і йдеться в ньому про реформування військових закладів Сухопутного шляхетного корпусу, який ще довго залишався основним світським навчальним закладом з власною друкарнею, театром та гуманітарними гуртками.

У висновках найважливішою для Ігоря Федюкіна $є$ дихотомія між «державою» та «освітою». Автор подовжує свої міркування на кінець XVIII ст., зосереджуючись на прикладах імператорів Олександра та Миколи I, передусім на підготовці кадрів для війська близькій для себе сфері. За його спостереженням, ідеї «модернізації» чи «вестернізації» будуть поширюватися через освітні проекти, а добре впорядкована держава матиме і прообраз, і засоби втілення в подобі Сухопутного шляхетного корпусу з його суворим мініхівським регламентом. Утім, важливою стала й альтернатива - функціонування «недержавної» приватної освіти на західних околицях імперії: Україні, Смоленську, Новгороді (с. 211), а також освітні ініціативи у Прибалтиці та присутність носіїв київської освіти (с. 212) з власними традиціями. Проте освітні проекти, на думку Ігоря Федюкіна, не могли би розвинутися без адміністративного втручання. За приклад використано випадок появи Харківського імператорського університету, де ініціатор його відкриття Василь Каразін переконував місцеве дворянство в корисності пожертв на нього передусім як емісар з центру. Підсумовуючи, автор наголошує, що однією з основних проблем освітньої історії $€$ існування або навчальних закладів, альтернативних державним, або таких, де втручання адміністрацій було радше формальним, і ширше - наскільки незалежна освіта взагалі виявлялася можливою та представленою в імперії.

Історик - дитя сучасності: книжку завершує абзац про політичні зміни 1990-х рр., що призвели до появи Європейського університету у Петербурзі та Вищої школи економіки у Москві - потужних, 
певний час гуманітарних приватних закладів, які з часом таки підпадали під тиск адміністративного державного домінування.

Не обійшлося у книжці без дрібних казусів. Так, білгородського єпископа та засновника Харківського колегіуму (певного наслідку реалізації статей Духовного Регламента) Єпифанія Тихорського названо Тихорецьким (Tikhoretskii) (c. 52), а в покажчику як одну особу подано Михайла Михайловича Голіцина (старшого, 1675-1730), президента Військової колегії), і Михайла Михайловича Голіцина (молодшого, 1684-1764), президента Колегії адміралтейств.

Робота Ігоря Федюкіна - важливе явище в історіографії історії освіти. Вона почасти відповідає на питання, як державна політика впливає на становлення освіти, як політичні зміни спричиняють реформування та виникнення навчальних закладів. Військовоосвітні інституції $є$ визначальними у період становлення імперії на досліджуваному просторі, а офіцерський дворянський прошарок, поза сумнівом, стане промоутером змін, змов та заколотів, як це станеться у грудні 1825 р. у Санкт-Петербурзі.

Серед дискусійних питань, не заторкнутих у книжці, можна згадати взаємини імперії та околиць. Дослідження доволі «столичне», хоч тим часом поза російськими столицями існував світ, де діяв не лише «Духовний регламент», а й висувалися сміливі адміністративні пропозиції - для прикладу, проект початку царювання Катерини II про школу для солдатських дітей і друкарню в фортеці святої Єлизавети Олексія Мельгунова ${ }^{3}$. Так само складно зрозуміти, що відбувалося у сфері освіти на західних територіях, приєднаних до імперії за поділами Речі Посполитої, особливо коли йдеться про великі освітні новації у єзуїтських колегіях перед ліквідацією Товариства ${ }^{4}$, діяльність Едукаційної комісії ${ }^{5}$ та монаших орденів ${ }^{6}$. Приєднані терени сучасних Литви, Білорусі та України було вкрито мережею шкіл та приватних друкарень, інакших як «германські

${ }^{3}$ А.Н. Пашутин, Исторический очерк города Елисаветграда (Елисаветград, 1897), 17.

${ }^{4}$ Основна праця з даного приводу: Kazimierz Puchowski, Jezuitckie kolegia szlacheckie Rzeczpospolitej obojga Narodów (Gdańsk: Wydawnictwo Uniwersytetu Gdańskiego, 2007).

${ }^{5}$ Щодо навчальних проектів див.: W. Grabski, Prekursorzy idei Komisji Edukacji Narodowej (Warszawa 2000).

${ }^{6}$ Див., наприклад, останню вагому працю з численними прикладами: Beata Lorens, Bazylianie Prowincji Koronnej w latach 1743-1780 (Rzeszow, 2014). 
порядки» навчальних закладів військового типу. Питання складнощів взаємодії державної політики та місцевих практик і політичної мети освіти вочевидь стане основним і щодо навчальних практик на околицях імперіï, але часи «еarly modern» уже закінчаться.

Ще одне питання, яке автор почасти оминув увагою, - це вплив тієї моделі освіти, що вже існувала, зокрема і Києво-Могилянської академії, на становлення описаних у книжці освітніх практик. Чи дійсно Церква й духовні заклади перебували поза «адміністративним колом» формування нової професійної освіти, чи, можливо, такий вплив усе ж існував? Зокрема, у випадку Сухопутного шляхетного корпусу варто згадати про залучення до викладання уже з 1732 р. двох київських богословів, законоучителів Луки Конашевича та Варлама Скамницького ${ }^{7}$. Виявлення таких зв'язків та поєднань видається важливою перспективою для подальших студій.

\section{Bibliography}

Fedukin, Igor. «"Prozhektery” kak administrativnyje predprinimateli: stanovlenie rannemodernykh gosudarstvennykh institutov i individualnaja iniciaativa.» In «Regularnaja akademia uchrezhdena budet»: Obrazovatelnyje proekty $v$ Rossii v pervoj polovine XVIII veka, 3-13. Moskva: Novoje izdatelstvo, 2015.

Grabski, W. Prekursorzy idei Komisji Edukacji Narodowej. Warszawa 2000.

Lorens, Beata. Bazylianie prowincji koronnej w latach 1743-1780. Rzeszow: Wydawnictwo Uniwersytetu Rzeszowskiego, 2014.

Pashutin, A. N. Istoricheskij ocherk goroda Yelisavetgrada. Yelisavetgrag, 1897.

Pavlov Silvanskij, N. P. Proekty reform v zapiskakh sovremennikov Petra Velikogo: Opyt izuchenia russkikh proektov i neizdannyje teksty. Sankt-Peterburg: Tip. V. Kirshbauma, 1897.

Puchowski, Kazimierz. Jezuitckie kolegia szlacheckie Rzeczpospolitej obojga Narodów. Gdańsk: Wydawnictwo Uniwersytetu Gdańskiego, 2007.

Rossijskij gosudaarstvenyj istoricheskij arkhiv, f. 796, op. 14, d. 359.

Serov, D. Administracia Petra Pervogo. Moskva: OGI, 2007.

${ }^{7}$ Российский государственный исторический архив, ф. 796, оп. 14, д. 359, л. $2-3$. 